\title{
Effect of particle size of lucerne hay on chewing activity, digestion and energy balance of Chinese Holstein heifers
}

\author{
Q.B. Kong, X.M. Zhang1, F. Mo, S.L. Li and M. Ma \\ College of Animal Science and Technology, China Agriculture University \\ Yuanmingyuan West Road 2, Beijing 100094, P.R. China
}

\begin{abstract}
Three 8-month-old Chinese Holstein heifers weighing $300 \pm 22.4 \mathrm{~kg}$ were selected for a $3 \times 3 \mathrm{Latin}$ square design to study the effects of chopped length of lucerne hay $(2,4 \mathrm{~cm}$, and natural length) on chewing activity and feed utilization efficiency. Results showed that increasing the chopped length of lucerne hay increased eating bout, time spent for eating hay, concentrate and ration, ruminating and total chewing activity. Digestibility was unaffected by the treatments. Decreasing chopped length of lucerne hay decreased heat production and increased energy retained in body.
\end{abstract}

KEY WORDS: lucerne hay, chopped length, chewing activity, energy metabolism, digestibility, heifers

\section{INTRODUCTION}

Over the past decades, only several studies were related to the effects of particle size of forages on chewing activities, digestibility and energy metabolism of heifers. Jaster and Murphy (1983) fed long, coarsely and finely chopped lucerne hay to heifers. As particle size decreased, eating time and ruminating boluses per minute decreased, however ruminating time was unaffected. Belyea et al. (1985) fed long (LLH) and short (SLH) lucerne hay to heifers and found that digestibility of DM, $\mathrm{NDF}, \mathrm{ADF}$, cell wall and the ratio DE/GE, ME/GE were higher for LLH than for SLH. Adams et al. (1988) reported that digestibility of DM and NDF of heifer diets was unaffected by chopped length of fescue hay. It is commonly believed that energy utilization efficiency of diet is affected by animal age, diet ingredient and

\footnotetext{
${ }^{1}$ Corresponding author: e-mail: xiaomingzh@cau.edu.cn
} 
composition, ratio of concentrate to forage, plane of nutrition, physical form of feed, etc. Particle size of forages affected chewing activities, physical filling of reticulorumen, ruminal fermentation and passage rate through the digestive tract. All these are associated with heat increment. However, limited data are available on the effects of chopped length of hay on energy metabolism parameters, such as heat production (HP), methane production and energy retained in body (RE) of heifer. The objective of this study was to investigate the effects of various chopped length of lucerne hay on feed digestibility, chewing activities and energy metabolism of heifers.

\section{MATERIAL AND METHODS}

Three 8-month-old Chinese Holstein heifers weighing 300 $\pm 22.4 \mathrm{~kg}$ were assigned randomly to a $3 \times 3$ Latin square. During each of the $17 \mathrm{~d}$ periods with $14 \mathrm{~d}$ for treatment adaptation and $3 \mathrm{~d}$ for data collection, animals were offered one of three diets that were chemically similar but varied in lucerne hay particle size which was short (S), medium (M) and long (L) with a theoretical cut length of 2,4 cm and natural length, respectively. The experimental diets were formulated according to the Chinese Feeding Standard of Dairy Cattle. The ingredients and composition of the diets and particle distributions of lucerne hay were presented in Tables 1 and 2. The daily diet for each heifer was composed of about $3.6 \mathrm{~kg}$ lucerne hay, $0.7 \mathrm{~kg}$ Chinese wild rye and 2.3 $\mathrm{kg}$ concentrate. The lucerne hay, Chinese wild rye and concentrate were separately fed to the heifer at 07.00 and $18.00 \mathrm{~h}$, respectively. Heifers were housed in a free stall for $11 \mathrm{~d}$ and then transferred to the open-circuit respiration chambers for $3 \mathrm{~d}$ equipment adaptation prior to the $3 \mathrm{~d}$ data collection period.

During the period of data collection, the feeds intake, faeces and urine excretion were measured. The oxygen consumption $\left(\mathrm{O}_{2}\right)$, carbon dioxide production $\left(\mathrm{CO}_{2}\right)$ and methane production $\left(\mathrm{CH}_{4}\right)$ of the animals were determined. Samples of the concentrate, forages, faeces and urine were collected and treated properly for further analysis. Dry matter (DM) and crude protein (CP) contents in samples were determined with the methods of AOAC (1995). NDF and ADF of the diets and faeces were analysed by the procedure of Goering and Van Soest (1970). Gross energy (GE) concentration in forages, concentrate, faeces and urine was determined in an adiabatic bomb calorimeter. The particle size of lucerne hay was measured with the Penn State Particle Separator (Mertens, 1997). Energy in $\mathrm{CH}_{4}$ $\left(\mathrm{CH}_{4} \mathrm{E}\right)$, heat production and energy retained in body were calculated according to the Brouwer (1965) equations:

$$
\begin{gathered}
\mathrm{CH}_{4} \mathrm{E}(\mathrm{KJ})=\mathrm{CH}_{4}(\mathrm{~L}) \times 39.54 \\
\mathrm{HP}=16.175 \times \mathrm{O}_{2}(\mathrm{~L})+5.021 \times \mathrm{CO}_{2}(\mathrm{~L})-2.167 \times \mathrm{CH}_{4}(\mathrm{~L})-5.9873 \times \text { urinary-N }(\mathrm{g}) \\
\mathrm{RE}=\mathrm{ME}-\mathrm{HP}
\end{gathered}
$$


Eating and ruminating activities were measured in $\mathrm{d} 16$ and $\mathrm{d} 17$ of each period using a video monitoring system. Data were expressed as daily eating time for diet and lucerne hay, ruminating time and total chewing time. Activities per unit of DMI and the hay were calculated. Eating bouts and DMI per bout were also observed.

Table 1. Ingredients and composition of diets, DM basis

\begin{tabular}{|c|c|c|c|c|c|}
\hline \multirow{2}{*}{ Item } & \multicolumn{3}{|c|}{ Diets } & \multirow{2}{*}{ SEM $^{1}$} & \multirow{2}{*}{$\mathrm{P}$} \\
\hline & $\mathrm{S}$ & $\mathrm{M}$ & $\mathrm{W}$ & & \\
\hline \multicolumn{6}{|l|}{ Ingredient, \% } \\
\hline lucerne hay & 55.25 & 55.25 & 55.25 & & \\
\hline Chinese wild rye-grass & 9.71 & 9.71 & 9.71 & & \\
\hline cracked maize & 29.18 & 29.18 & 29.18 & & \\
\hline soyabean meal & 3.89 & 3.89 & 3.89 & & \\
\hline dicalcium phosphate & 0.90 & 0.90 & 0.90 & & \\
\hline premix & 1.00 & 1.00 & 1.00 & & \\
\hline \multicolumn{6}{|l|}{ Composition, \% } \\
\hline $\mathrm{DM}$ & 91.22 & 91.58 & 90.88 & 0.31 & 0.12 \\
\hline $\mathrm{CP}$ & 14.08 & 13.84 & 14.16 & 0.18 & 0.13 \\
\hline $\mathrm{NDF}$ & 37.47 & 37.35 & 37.27 & 0.24 & 0.57 \\
\hline $\mathrm{ADF}$ & 27.09 & 27.19 & 27.26 & 0.54 & 0.99 \\
\hline $\mathrm{Ca}$ & 0.61 & 0.61 & 0.61 & & \\
\hline $\mathrm{P}$ & 0.38 & 0.38 & 0.38 & & \\
\hline
\end{tabular}

${ }^{1}$ standard error of mean

Table 2. Distribution of particles, particle length of lucerne hay, $\%$

\begin{tabular}{lccc}
\hline \multirow{2}{*}{ Penn State Particle Separator } & \multicolumn{3}{c}{ Lucerne hay } \\
\cline { 2 - 4 } & $\mathrm{S}$ & $\mathrm{M}$ & $\mathrm{W}$ \\
\hline Upper, 19-mm & 62 & 72 & 89 \\
Middle, 8-mm & 16 & 14 & 4 \\
Lower, 1.18-mm & 13 & 10 & 5 \\
Bottom Pan & 9 & 4 & 2 \\
\hline
\end{tabular}

\section{RESULTS}

The results were presented in Tables 3, 4 and 5. On a DM basis, increasing chopped length of lucerne hay increased the time spent for eating hay and diets, ruminating and chewing. Eating and ruminating contributed 26 and $74 \%$ to the increase of chewing activities, respectively. Expressed as $\mathrm{min} / \mathrm{kg}$ DMI, differences in time spent for eating hay and diets, ruminating and chewing were observed for the diets with different chopped length of the hay. Ruminating activities contributed primarily $(71 \%)$ to the increment of chewing activities. As chopped length increased from $2 \mathrm{~cm}$ to natural length, eating bouts increased from 4 to 8 numbers, while DMI per bout decreased from 1.45 to $0.77 \mathrm{~kg}$. 
Table 3. Effects of chopped length of lucerne hay on chewing activity

\begin{tabular}{|c|c|c|c|c|c|}
\hline \multirow{2}{*}{ Item } & \multicolumn{3}{|c|}{ Diets } & \multirow{2}{*}{ SEM } & \multirow{2}{*}{$\mathrm{P}$} \\
\hline & $\mathrm{S}$ & $\mathrm{M}$ & $\mathrm{W}$ & & \\
\hline \multicolumn{6}{|l|}{ Chewing activities, $\mathrm{min} / \mathrm{d}$} \\
\hline eating time of lucerne hay & $50.9^{\mathrm{Bc}}$ & $57.7^{\mathrm{ABb}}$ & $65.7^{\mathrm{Aa}}$ & 1.18 & 0.02 \\
\hline total eating time & $82.3^{\mathrm{C}}$ & $90.4^{\mathrm{B}}$ & $97.0^{\mathrm{A}}$ & 1.61 & $<0.01$ \\
\hline ruminating time & $346.5^{\mathrm{b}}$ & $372.1^{\mathrm{ab}}$ & $387.8^{\mathrm{a}}$ & 2.94 & 0.05 \\
\hline chewing time & $428.8^{c}$ & $462.4^{b}$ & $484.7^{\mathrm{a}}$ & 3.35 & 0.03 \\
\hline \multicolumn{6}{|l|}{ Chewing activities, $\mathrm{min} / \mathrm{kg}$ DMI } \\
\hline eating time of lucerne hay & $14.8^{\mathrm{C}}$ & $16.3^{\mathrm{B}}$ & $19.0^{\mathrm{A}}$ & 0.62 & $<0.01$ \\
\hline eating time & $13.0^{\mathrm{Bc}}$ & $14.2^{\mathrm{ABb}}$ & $15.5^{\mathrm{Aa}}$ & 2.80 & 0.02 \\
\hline ruminating time & $55.7^{\mathrm{Bc}}$ & $57.4^{\mathrm{Bb}}$ & $62.0^{\mathrm{Aa}}$ & 1.32 & $<0.01$ \\
\hline chewing time & $69.0^{\mathrm{b}}$ & $72.5^{\mathrm{ab}}$ & $77.7^{\mathrm{a}}$ & 1.46 & 0.05 \\
\hline Eating bouts, numbers /d & $4.3^{\mathrm{b}}$ & $5.6^{\mathrm{b}}$ & $8.1^{\mathrm{a}}$ & 0.31 & 0.02 \\
\hline DMI, kg/bout & $1.45^{\mathrm{a}}$ & $1.15^{\mathrm{a}}$ & $0.77^{b}$ & 0.19 & 0.04 \\
\hline
\end{tabular}

within a row, means without a common capital letter are significantly different $(\mathrm{P} \leq 0.01)$, means without a common small letter are different $(\mathrm{P} \leq 0.05)$

Table 4. Effects of chopped length of lucerne hay on nutrients digestibility

\begin{tabular}{|c|c|c|c|c|c|}
\hline \multirow{2}{*}{ Item } & \multicolumn{3}{|c|}{ Diets } & \multirow{2}{*}{ SEM } & \multirow{2}{*}{$\mathrm{P}$} \\
\hline & $\mathrm{S}$ & $\mathrm{M}$ & $\mathrm{W}$ & & \\
\hline $\mathrm{BW}, \mathrm{kg}$ & 301.40 & 301.90 & 306.30 & 4.12 & 0.70 \\
\hline \multicolumn{6}{|l|}{$D M I, \mathrm{~kg} / \mathrm{d}$} \\
\hline lucerne hay & $3.43^{\mathrm{b}}$ & $3.54^{\mathrm{a}}$ & $3.48^{\mathrm{ab}}$ & 1.21 & 0.06 \\
\hline DMI & 6.23 & 6.39 & 6.28 & 2.04 & 0.22 \\
\hline NDF & 2.36 & 2.41 & 2.37 & 2.12 & 0.39 \\
\hline $\mathrm{ADF}$ & 2.12 & 2.17 & 2.12 & 0.62 & 0.33 \\
\hline $\mathrm{CP}$ & 0.88 & 0.90 & 0.88 & 0.96 & 0.19 \\
\hline
\end{tabular}

Feed efficiency, \%

$\begin{array}{llllll}\text { DM } & 66.19 & 66.06 & 64.28 & 1.12 & 0.05 \\ \text { NDF } & 53.51 & 54.23 & 51.13 & 1.71 & 0.53 \\ \text { ADF } & 59.82 & 63.40 & 61.43 & 1.18 & 0.30 \\ \text { CP } & 67.41 & 67.14 & 68.39 & 1.02 & 0.67\end{array}$

\begin{tabular}{llllll} 
N retained, \% & 7.30 & 5.10 & 11.32 & 2.34 & 0.35 \\
\hline
\end{tabular}

within a row, means without a common superscript are significantly different $(\mathrm{P} \leq 0.05)$

Digestibility of rations was unaffected by chopped length of lucerne hay. Increasing chopped length resulted in an increase of heat production and a reduction of energy retained in body and ratio RE/ME. No differences were observed among other metabolism parameters. However, with increasing length, urinary energy 
(UE), UE/DE, DE/GE tended to decrease, while methane production, energy in $\mathrm{CH}_{4}$ and $\mathrm{CH}_{4} \mathrm{E} / \mathrm{DE}$ increased, numerically.

Table 5. Effects of chopped length of lucerne hay on energetic efficiency and methane production

\begin{tabular}{|c|c|c|c|c|c|}
\hline \multirow{2}{*}{ Item } & \multicolumn{3}{|c|}{ Diets } & \multirow{2}{*}{ SEM } & \multirow{2}{*}{$\mathrm{P}$} \\
\hline & $\mathrm{S}$ & $\mathrm{M}$ & W & & \\
\hline \multicolumn{6}{|c|}{ Energy input and output, $M J / d$} \\
\hline GE & 112.55 & 115.52 & 113.54 & 2.79 & 0.21 \\
\hline $\mathrm{DE}$ & 75.78 & 76.76 & 76.30 & 1.30 & 0.27 \\
\hline ME & 61.91 & 61.27 & 62.66 & 1.61 & 0.43 \\
\hline UE & 7.59 & 8.23 & 6.40 & 2.49 & 0.22 \\
\hline $\mathrm{CH}_{4} \mathrm{E}$ & 6.28 & 7.26 & 7.24 & 1.18 & 0.99 \\
\hline $\mathrm{HP}^{4}$ & $54.64^{\mathrm{b}}$ & $54.59^{\mathrm{b}}$ & $56.75^{\mathrm{a}}$ & 2.54 & 0.05 \\
\hline $\mathrm{RE}$ & $7.27^{\mathrm{a}}$ & $6.68^{\mathrm{a}}$ & $5.91^{\mathrm{b}}$ & 1.79 & 0.04 \\
\hline \multicolumn{6}{|l|}{ Energy efficiencies, \% } \\
\hline $\mathrm{DE} / \mathrm{GE}$ & 67.27 & 66.44 & 67.17 & 2.67 & 0.69 \\
\hline $\mathrm{ME} / \mathrm{GE}$ & 54.90 & 53.03 & 53.09 & 1.23 & 0.38 \\
\hline $\mathrm{ME} / \mathrm{DE}$ & 81.70 & 79.82 & 82.12 & 2.54 & 0.41 \\
\hline $\mathrm{UE} / \mathrm{DE}$ & 10.12 & 10.74 & 8.43 & 2.76 & 0.29 \\
\hline $\mathrm{CH}_{4} \mathrm{E} / \mathrm{DE}$ & 8.32 & 9.44 & 9.54 & 1.23 & 0.11 \\
\hline $\mathrm{RE} / \mathrm{ME}$ & $11.74^{\mathrm{a}}$ & $10.90^{\mathrm{a}}$ & $9.43^{\mathrm{b}}$ & 2.63 & 0.04 \\
\hline $\mathrm{CH}_{4}$ yield, $1 / \mathrm{kg} \mathrm{DM}$ & 25.56 & 28.70 & 29.28 & 0.97 & 0.19 \\
\hline
\end{tabular}

within a row, means without a common superscript are different $(\mathrm{P} \leq 0.05)$

\section{DISCUSSION}

The reduction of eating bouts for the diet with short chopped hay indicats that heifer prefer short hay to long one. In addition, DMI per bout is affected by density of diet. Heifers spent more time for chewing long hay before swallowing. Passage rate through the digestive tract for long hay may be lower than that for short hay, which resulted in an increase of ruminating activity.

Conflicting results on effects of chopped length of forage on digestibility of heifers were reported. Jaster and Murphy (1983) reported that feed digestibility decreased as chopped length of lucerne hay increased, while Belyea et al. (1985) found a higher digestibility of DM, NDF, ADF and cell wall for short lucerne hay than for long one, but digestibility of $\mathrm{CP}$ and nitrogen balance were unaffected by treatment. The results of our study were in agreement with those of Adams et al. (1988) with heifers on a diet containing fescue hay of different chopped length. The different results between study of Jaster and Murphy (1983) and our study can be partly explained by the different diets and animal age. A more nutritionally balanced and practical diet was offered to heifer in this study than that in the study 
of Jaster and Murphy (1983). Category and proportion of rumen microorganisms may be a potential factor affecting feed digestibility.

Heat production is derived from net energy for maintenance and heat increment. The differences of heat production among the treatments primarily came from heat increment in present study because the body weights of heifers were similar. Heat increment is derived from chewing activities, passage progressing through digestive tract, fermentation, absorption and organic metabolism, etc. Much eating and ruminating time for the diet with natural length lucerne hay lead to higher heat increment compared to the diet with chopped hay. In addition, larger volume for the diet with natural length lucerne hay compared to the diet with chopped hay enlarged the digestive tract size and resulted in stronger organic metabolism activities which are associated with heat increment. Energy retained in body (RE/ DE) increased as heat increment reduced.

\section{CONCLUSIONS}

Decreasing chopped length of lucerne hay decreased chewing activities, especially chewing time. Utilization efficiency of normal ingredient was unaffected by chopped length of the hay. With increasing length, digestibility of DM, NDF and ADF tended to decrease numerically. Cutting improved energy efficiency of the diets. Increasing chopped length of hay increased heat production and reduced energy retained in body. With increasing length, urinary energy, UE/GE, DE/GE of ration tended to decrease, while methane production, energy in $\mathrm{CH}_{4}, \mathrm{CH}_{4} \mathrm{E} / \mathrm{ME}$ increased. Theoretical cut length of $2 \mathrm{~cm}$ of lucerne hay was more beneficial to heifers than that of $4 \mathrm{~cm}$ and natural length.

\section{REFERENCES}

Adams M.W., Belyea R.L., Martz F.A., 1988. Effect of variety and particle size upon utilization of fescue hay by lactating dairy cows and heifers. J. Dairy Sci. 71, 1275-1282

AOAC, 1995. Association of Official Analytical Chemists, Official Methods of Analysis. 16th Edition. Arlington, VA

Belyea R.L., Marin P.J., Sedgwick H.T., 1985. Utilizaiton of chopped and long alfalfa by dairy heifers. J. Dairy Sci. 68, 1297-1301

Brouwer E., 1965. Report of sub-committee on constants and factors. In: K.L. Blaxter (Editor). Energy Metabolism. EAAP Publication No. 11. Academic Press, London, pp. 442-443

Goering H.K., Van Soest P.J., 1970. Forage Fiber Analysis. Agriculture Handbook No. 379. USDA. Washington, DC

Jaster E.H., Murphy M.R., 1983. Effects of varying particles size of forage on digestion and chewing behavior of dairy heifers. J. Dairy Sci. 66, 302-307

Mertens D.R., 1997. Creating a system for meeting the fiber requirements of dairy cattle. J. Dairy Sci. $80,1463-1482$ 